University of Nebraska - Lincoln

DigitalCommons@University of Nebraska - Lincoln

\title{
Spectroscopic and Diffraction Study of Uranium Speciation in Contaminated Vadose Zone Sediments from the Hanford Site, Washington State
}

\author{
Jeffrey Catalano \\ Stanford University, catalano@pangea.stanford.edu \\ Steven Heald \\ Argonne National Laboratory \\ John M. Zachara \\ Pacific Northwest National Laboratory, john.zachara@pnl.gov \\ Gordon Brown Jr. \\ Stanford University
}

Follow this and additional works at: https://digitalcommons.unl.edu/usdoepub

Part of the Bioresource and Agricultural Engineering Commons

Catalano, Jeffrey; Heald, Steven; Zachara, John M.; and Brown, Gordon Jr., "Spectroscopic and Diffraction Study of Uranium Speciation in Contaminated Vadose Zone Sediments from the Hanford Site, Washington State" (2004). US Department of Energy Publications. 226.

https://digitalcommons.unl.edu/usdoepub/226

This Article is brought to you for free and open access by the U.S. Department of Energy at DigitalCommons@University of Nebraska - Lincoln. It has been accepted for inclusion in US Department of Energy Publications by an authorized administrator of DigitalCommons@University of Nebraska - Lincoln. 
Spectroscopic and Diffraction Study of Uranium Speciation in Contaminated Vadose Zone Sediments from the Hanford Site, Washington State

\author{
JEFFREY G. CATALANO,*,† \\ STEVEN M. HEALD, $\neq$ \\ JOHN M. ZACHARA, \& AND \\ GORDON E. BROWN, JR. †."
}

Surface and Aqueous Geochemistry Group, Department of Geological and Environmental Sciences, Stanford University, Stanford, California 94305-2115, PNC-CAT, Advanced Photon Source, Argonne National Laboratory, Argonne, Illinois 60439, Environmental Dynamics \& Simulation, Pacific Northwest National Laboratory, P.O. Box 999, MS K8-96, Richland, Washington 99352, and Stanford Synchrotron Radiation Laboratory, SLAC, MS 69, 2575 Sand Hill Road, Menlo Park, California 94025

Contamination of vadose zone sediments under tank BX102 at the Hanford site, Washington, resulted from the accidental release of 7-8 metric tons of uranium dissolved in caustic aqueous sludge in 1951. We have applied synchrotron-based X-ray spectroscopic and diffraction techniques to characterize the speciation of uranium in samples of these contaminated sediments. U LוII-edge X-ray absorption fine structure (XAFS) spectroscopic studies demonstrate that uranium occurs predominantly as a uranium(VI) silicate from the uranophane group of minerals. XAFS cannot distinguish between the members of this mineral group due to the near identical local coordination environments of uranium in these phases. However, these phases differ crystallographically, and can be distinguished using X-ray diffraction (XRD) methods. As the concentration of uranium was too low for conventional XRD to detect these phases, $X$-ray microdiffraction ( $\mu$ XRD) was used to collect diffraction patterns on $\sim 20$ $\mu \mathrm{m}$ diameter areas of localized high uranium concentration found using microscanning $X$-ray fluorescence ( $\mu \mathrm{SXRF}$ ). Only sodium boltwoodite, $\mathrm{Na}\left(\mathrm{UO}_{2}\right)\left(\mathrm{SiO}_{3} \mathrm{OH}\right) \cdot 1.5 \mathrm{H}_{2} \mathrm{O}$, was observed; no other uranophane group minerals were present. Sodium boltw oodite formation has effectively sequestered uranium in these sediments under the current geochemical and hydrologic conditions. Attempts to remediate the uranium contamination will likely face significant diffic ulties because of the speciation and distribution of uranium in the sediments.

\section{Introduction}

The legacy of nuclear weapons production in the United States is vast quantities of low- and high-level nuclear waste

\footnotetext{
*Correspondingauthor phone: (650)723-7513; fax: (650)725-2199; e-mail: catalano@pangea.stanford.edu.

† Stanford University.

‡ Argonne National Laboratory.

$\S$ Pacific Northwest National Laboratory.

" Stanford Synchrotron Radiation Laboratory.
}

stored at former weapons complexes (1). At one such complex, the Hanford site in Washington State, World War II and Cold War era waste products associated with the extraction of $\mathrm{Pu}$ from spent fuels rods are stored in 177 underground storagetanks. Many of thesetanks, which range in size from 500000 to 1 million gal, have leaked in the past 50 years, discharging large quantities of radionuclides such as ${ }^{60} \mathrm{Co},{ }^{90} \mathrm{Sr},{ }^{99} \mathrm{Tc},{ }^{137} \mathrm{Cs},{ }^{152,154} \mathrm{Eu}$, and ${ }^{235,238 \mathrm{U}}$, as well-known carcinogens such as $\mathrm{CrO}_{4}{ }^{2-}$, into the vadose zone and underlying groundwater. Numerous studies are under way to assess the future mobility of these contaminants.

One area of particular concern at Hanford is a subsurface uranium plume associated with tank leakage in the BX tank farm in the 200 East Area. In 1951, overfilling of tank BX-102 resulted in the discharge of almost $350000 \mathrm{~L}$ of waste solution containing 7-8 metric tons of uranium. Recent estimates suggest the aqueoussludge consisted of high concentrations of dissolved $\mathrm{U}(\mathrm{VI})(0.5 \mathrm{M})$ and $\mathrm{PO}_{4}{ }^{3-}(0.36 \mathrm{M})$ and virtually all fission products except $\mathrm{Pu}$ in a 2.5-5.0 $\mathrm{M} \mathrm{Na}_{2} \mathrm{CO}_{3}$ solution with an estimated $\mathrm{pH}$ of 10 at temperatures in excess of 80 ${ }^{\circ} \mathrm{C}$ (2). To obtain information regarding the depth distribution and inventory of uranium in this subsurface plume, a borehole (299-E33-45) was drilled in 2001, and the sediment core was retrieved and archived for characterization (3). Samples with high solid-phase uranium concentrations were selected from the core for further analysis to understand the speciation of uranium in this plume, which is essential to predicting the future fate and transport of uranium under tank BX-102.

Important speciation parameters for uranium considered at this site, and in the environment in general, include the oxidation state of uranium, the type(s) and binding of uranium sorption complexes [if adsorbed], the type(s) of phase within which uranium is structural ly incorporated [if present in a three-dimensional precipitate(s) or uraniumcontaining phase(s)], the type(s) of associated phases, and the spatial distribution of uranium in the sediments on the grain and pore scale. The oxidation state of uranium has a strong effect on its mobility, as U(IV) is much less soluble than U (VI). Knowledge of thetype(s) of adsorption complexes or solid phases incorporating uranium is quiteimportant for accurate transport modeling as uranium in an adsorbed form should be much more mobile than uranium incorporated into a crystalline or amorphous precipitate, depending upon its solubility, the presence of complexing ligands such as carbonate or phosphate, and $\mathrm{pH}$. This is especially true for $\mathrm{U}(\mathrm{VI})$. Finally, understanding the phase associations and spatial distribution of uranium on the grain scal eis essential to understanding how available it might be to reaction with porewaters, and thus the factors affecting the kinetics of desorption/ dissolution of the uranium phase(s). Synchrotronbased X-ray techniques can provide information on the speciation of uranium in Hanford coresamples with minimal sample preparation.

In thepresent study, synchrotron-based X-ray techniques, including X-ray absorption fine structure (XAFS) spectroscopy, microscanning X-ray fluorescence ( $\mu \mathrm{SXRF}$ ), and X-ray microdiffraction ( $\mu \mathrm{XRD}$ ), were used to investigate the speciation of uranium in four vadose zone sediment samples from borehole 299-E33-45. The oxidation state of uranium was determined by X-ray absorption near edge structure (XANES) spectroscopy. The chemical form of uranium was probed using extended X-ray absorption fine structure (EXAFS) spectroscopy, and was further refined using $\mu$ XRD. Analyses of phase associations and the microscopic distribution of uranium in the Hanford vadose zone sediments are 


\section{TABLE 1. Sample Description}

$\begin{array}{lcc}\text { sample } & \text { uranium conc }{ }^{a}(\mathbf{p p m}) & \text { sample depth }\left(\mathrm{ft} \text { bgs) }^{\mathbf{b}}\right. \\ \text { 33AB } & 173 & 73.14-73.64 \\ 53 \mathrm{AB} & 246 & 118.79-119.29 \\ 61 \mathrm{AB} & 356 & 130.70-131.20 \\ 67 \mathrm{AB} & 289 & 141.00-141.50 \\ & & \\ { }^{a} \text { As determined by XRF (3). }{ }^{b} \text { Feet below ground surface. }\end{array}$

presented in a paper by McKinley et al. (4), complementary laser-induced fluorescence spectroscopy (LIFS) studies of these samples are presented in a paper by Wang et al. (5), and analyses of the desorption/dissolution of uranium from these samples are presented in a paper by Liu et al. (6).

\section{Experimental Methods}

Four U-contaminated sediment samples from borehole 299E33-45, drilled through the contaminant plume near tank BX-102, were obtained for analysis (Table 1). The samples were primarily unconsolidated sand comprised of quartz, plagioclase and potassium feldspars, and mica, with minor amphibole, chlorite, illite, and smectite(3). Moisturecontents were between 3 and 4 wt \%, and organic carbon contents were exceedingly low, $0.014-0.053$ wt \% (3). A $200-300 \mathrm{mg}$ portion of each sediment samplewas packed in Teflon sample holders, sealed with 10 mil Kapton tape, and then heat-sealed in polyethylene bags in preparation for XAFS analysis. U LIIIedge XAFS spectra were measured at room temperature on the Molecular Environmental Sciences Beamline 11-2 (7) at the Stanford Synchrotron Radiation Laboratory (SSRL) using a cryogenically cooled $\mathrm{Si}(220), \phi=90^{\circ}$, double-crystal monochromator. Fluorescence-yield data were collected using a high-throughput 30-element solid-state germanium detector. A collimating mirror before the monochromator was used for harmonic rejection, with a cutoff of $22 \mathrm{keV}$. Between 15 and 30 scans were collected for each sample. A yttrium metal foil was mounted between two ionization chambers downstream of the sample for energy calibration; the first inflection point in the yttrium K-edge was set to $17038 \mathrm{eV}$.

XAFS data were processed using EXAFSPAK (8) and the SixPACK (9) interface to IFEFFIT (10). XANES data were background-subtracted and normalized to an edge step of 1. After background subtraction, the EXAFS data were extracted and $\mathrm{k}^{3}$-weighted. Phase-shift and backscattering amplitude functions for quantitative EXAFS fitting were generated from the crystal structure of soddyite $\left[\left(\mathrm{UO}_{2}\right)_{2} \mathrm{SiO}_{4}\right.$. $2 \mathrm{H}_{2} \mathrm{O}$ ] (11) using FEFF 7 (12). The three multiple-scattering paths associated with the axial oxygen atoms of the uranyl cation were included in all fits as described by Hudson et al. (13).

Thin sections of samples $61 \mathrm{AB}$ and $67 \mathrm{AB}$ were prepared as described by Liu et al . (6). $\mu$ SXRF mapping was performed on these thin sections using a focused X-ray beam on APS beamline ID-20 (PNC-CAT). Focusing of the X-ray beam to a spot size of $20 \mu \mathrm{m} \times 20 \mu \mathrm{m}$ was accomplished using a pair of Kirkpatrick-Baez mirrors, and the incident beam was monochromatized using a Si(111) double-crystal monochromator. $\mu$ XANES spectra were collected on areas of high uranium concentration, with the edge position calibrated using a $Y$ foil as described above.

$\mu$ XRD patterns were collected on select areas in transmission geometry using phosphor image plates, which were read using a Fuji BAS2000 scanner. The resulting images were processed using FIT2D (14). The sample to detector distance and geometric corrections were calculated from patterns of $\mathrm{CeO}_{2}$ and $\mathrm{Si}$. After these corrections were applied, the $2 \mathrm{D}$ images were integrated radially to yield $1 \mathrm{D}$ powder

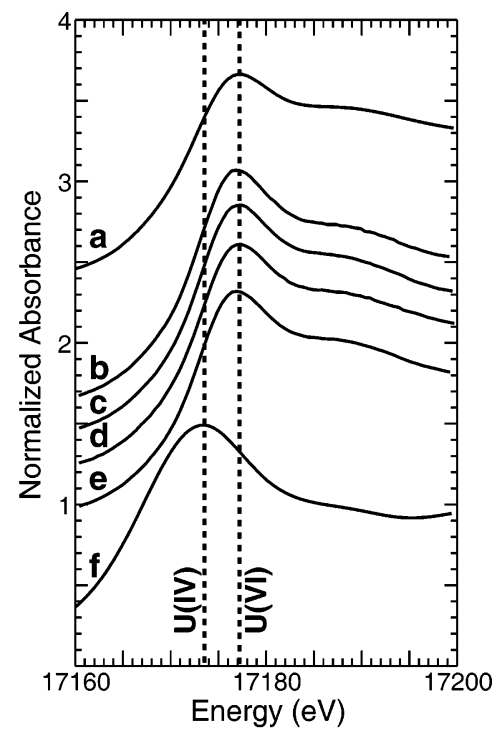

FIGURE 1. U LוII-edge XANES spectra of samples (b) 33AB, (c) 53AB, (d) $61 \mathrm{AB}$, and (e) 67AB compared to spectra of the (a) U(VI) standard schoepite and (f) U(IV) standard uraninite.
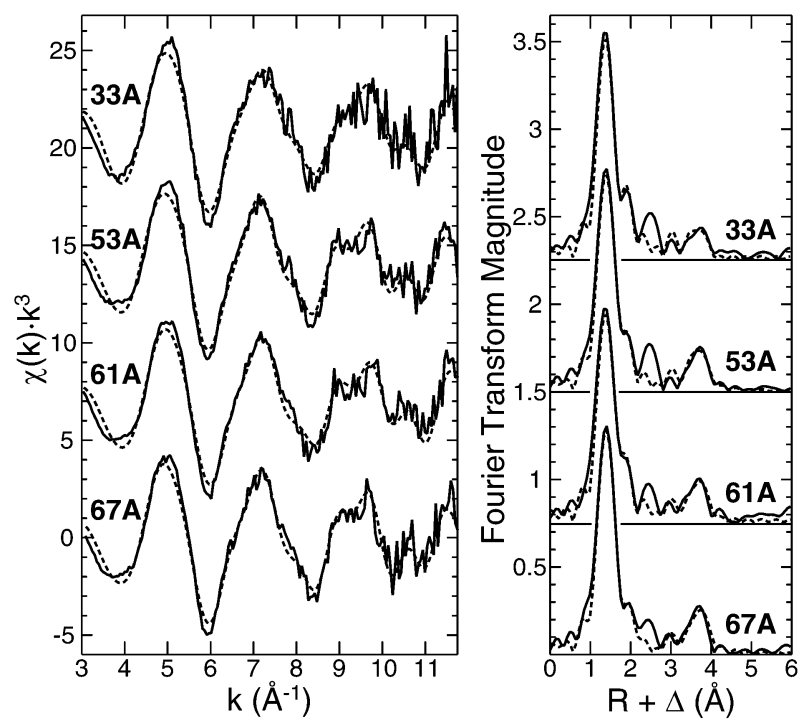

FIGURE 2. $U$ LIII-edge EXAFS (left) and Fourier transform (right) spectra (solid) and fits (dashed) of the four BX-102 samples.

diffraction patterns that could then be analyzed using standard techniques. Background subtraction, including removal of the scattering from the glass slide, and phase identification were performed in JADE 6.5 (Materials Data Inc., Livermore, CA); some peak assignments were done manually.

\section{Results and Discussion}

XANES Results. The $U L_{I I I}$-edge XANES spectra of the four samples were similar (Figure 1), and the edge energies of these spectra are consistent with that of $\mathrm{U}(\mathrm{VI})$. The broad shoulder occurring in the spectra at $\sim 17190 \mathrm{eV}$ indicates that $\mathrm{U}(\mathrm{VI})$ occurs as the uranyl moiety, $\mathrm{UO}_{2}{ }^{2+}(15,16)$. As the XANES spectra of $U(I V)$ and $U(V I)$ species lack intense, distinguishing characteristics that provide a highly accurate measure of the average oxidation state of $U$ in the samples, the presence of small amounts ( $<10 \%)$ of U (IV) cannot be ruled out.

EXAFSResults. I nitial comparison of the $L_{\text {III- }}$-edgeEXAFS spectra (Figure 2) of the four samples suggests there is little variability in the speciation of uranium among the samples. 
TABLE 2. $\chi_{v}{ }^{2}$ Differences between the EXAFS Spectra of the Four BX-102 Samples

\begin{tabular}{|c|c|c|c|c|c|}
\hline \multicolumn{2}{|c|}{ sample } & 33AB & $53 \mathrm{AB}$ & $61 A B$ & 67AB \\
\hline \multicolumn{2}{|c|}{$\begin{array}{l}33 A B \\
53 A B \\
61 A B \\
67 A B\end{array}$} & $\begin{array}{l}0.00 \\
0.37 \\
0.38 \\
0.55\end{array}$ & $\begin{array}{l}0.00 \\
0.17 \\
0.27\end{array}$ & $\begin{array}{l}0.00 \\
0.34\end{array}$ & 0.00 \\
\hline \multicolumn{6}{|c|}{ TABLE 3. EXAFS Fitting Results } \\
\hline sample & & $U-0_{a x}$ & $\mathrm{UO}_{\mathrm{eq} 1}$ & $\mathrm{U}-\mathbf{O}_{\text {eq2 }}$ & $U-U$ \\
\hline 33АВ & $\begin{array}{l}N^{a} \\
R^{c}(\AA) \\
\sigma^{2 d}\left(\AA^{2}\right)\end{array}$ & $\begin{array}{l}2^{b} \\
1.807(5) \\
0.0012(6)\end{array}$ & $\begin{array}{l}2.7(9) \\
2.29(1) \\
0.003(4)\end{array}$ & $\begin{array}{l}2.1(6) \\
2.47(3) \\
0.002^{b}\end{array}$ & $\begin{array}{l}1.3(6) \\
3.94(2) \\
0.0043^{b}\end{array}$ \\
\hline $53 \mathrm{AB}$ & $\begin{array}{l}N^{a} \\
R^{c}(\AA) \\
\sigma^{2 d}\left(\AA^{2}\right)\end{array}$ & $\begin{array}{l}2^{b} \\
1.807(4) \\
0.0016(5)\end{array}$ & $\begin{array}{l}3.0(8) \\
2.27(1) \\
0.003(3)\end{array}$ & $\begin{array}{l}2.0(4) \\
2.44(2) \\
0.003^{b}\end{array}$ & $\begin{array}{l}1.9(4) \\
3.95(1) \\
0.0043^{b}\end{array}$ \\
\hline $61 \mathrm{AB}$ & $\begin{array}{l}N^{a} \\
R^{c}(\AA) \\
\sigma^{2 d}\left(\AA^{2}\right)\end{array}$ & $\begin{array}{l}2^{b} \\
1.805(3) \\
0.0012(5)\end{array}$ & $\begin{array}{l}2.8(7) \\
2.28(1) \\
0.002(2)\end{array}$ & $\begin{array}{l}1.7(4) \\
2.46(2) \\
0.002^{b}\end{array}$ & $\begin{array}{l}1.8(4) \\
3.94(1) \\
0.0043^{b}\end{array}$ \\
\hline $67 A B$ & $\begin{array}{l}N^{a} \\
R^{c}(\AA) \\
\sigma^{2 d}\left(\AA^{2}\right)\end{array}$ & $\begin{array}{l}2^{b} \\
1.808(4) \\
0.0012(5)\end{array}$ & $\begin{array}{l}2.8(7) \\
2.26(1) \\
0.002(2)\end{array}$ & $\begin{array}{l}2.1(5) \\
2.44(2) \\
0.002^{b}\end{array}$ & $\begin{array}{l}1.9(4) \\
3.95(1) \\
0.0043^{b}\end{array}$ \\
\hline $\begin{array}{l}\text { the uncer } \\
\mathrm{O}_{a x} \text { shell, }\end{array}$ & $\begin{array}{l}\text { nation nu } \\
\text { standard } \\
\text { inty in th } \\
0.02 \AA \mathrm{fc}\end{array}$ & ast digit. c Ir & $\begin{array}{l}\text { ratomic di } \\
\text { Debye }-V\end{array}$ & fixed durin & $\begin{array}{l}\text { itting. The } \\
\text { resenting } \\
1 \text { A for the }\end{array}$ \\
\hline
\end{tabular}

Calculation of reduced $\chi^{2}$ differences, $\chi_{v}{ }^{2}$, as described by Catalano and Brown (17), yields values between 0.17 and 0.55 for the spectra (Table 2). Spectra with $\chi_{\nu}{ }^{2}$ values in this range are effectively identical (17), with the variability due to data collection and processing errors and noise. Considering the extent of uranium contamination in the subsurface [elevated uranium concentrations have been detected 70$170 \mathrm{ft}$ below ground surface (3) ], significantly more variability in the EXAFS spectra would be expected if multiple uranium species were present. It is highly unlikely that multiple uranium species would occur in exactly the sameproportions in all four samples.

The EXAFS spectra were initially fit to a structural model (Figure 2) using thephase-shift and backscattering amplitude functions described above. Fits to thefirst oxygen shell (Table 3) are in good agreement with the local structure of uranyl observed in natural samples (18): two oxygen atoms at a distance of about $1.8 \AA\left(\mathrm{U}-\mathrm{O}_{\mathrm{ax}}\right)$, and four to six oxygen atoms in the range of $2.2-2.5 \AA\left(\mathrm{U}-\mathrm{O}_{\text {eq1 }}, \mathrm{U}-\mathrm{O}_{\text {eq2 }}\right)$. These data agree with the XANES results discussed above, confirming that uranium occurs predominantly in the $6+$, uranyl form.

Further fitting of structural parameters to the uranium $L_{\text {III }}$ EXAFS data were limited to that of a uranium shell at distances $>3.7 \AA$. [Weare not aware of any uranium minerals with a uranium shell distance less than this value.] As the composition of the uranium-bearing phase(s) present is unknown, fitting backscattering atoms in the intermediate range of $2.5-3.7 \AA$ is not justified, as any number of potential structural ligands may occur at these distances, including carbonate, nitrate, phosphate, silicate, and sulfate. The scattering intensity from such groups is often relatively weak, and fitting these ligands without any a priori knowledge of their possible identity is difficult to justify. Fitting uranium backscatterers, however, is quite reasonable dueto their large scattering amplitude; uranium backscatterers were fit to all four samples (Table 3). Comparison of the average EXAFSderived uranium-uranium distance $(3.94 \AA)$ to those of known uranium mineral structures (Figure 3 ) suggests that this distance is most consistent with the presence of a

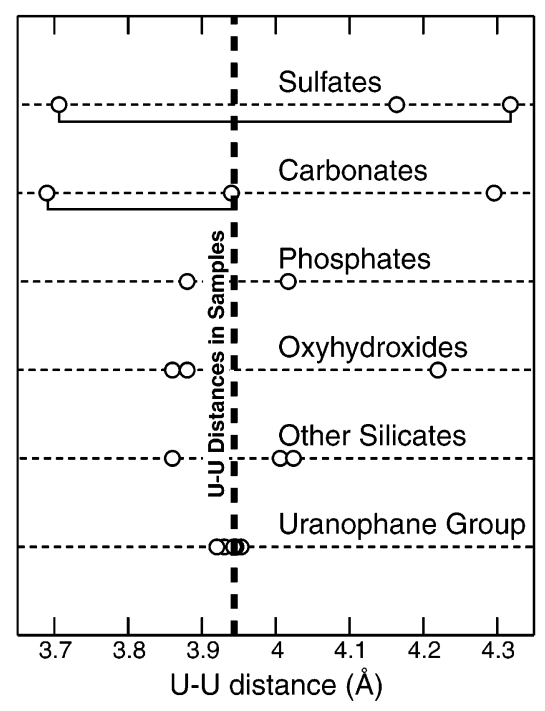

FIGURE 3. Comparison of the uranium-uranium distances determined from EXAFS (vertical dashed line) to the XRD-derived values for know $n$ uranium phases $(11,19-34)$. Single phases with multiple uranium-uranium distances are linked with an underscore.

TABLE 4. $\chi_{v}^{2}$ Differences between EXAFS Spectra of Four BX-102 Samples and of Uranophane Group Minerals from Catalano and Brown (17)

\begin{tabular}{|c|c|c|c|c|}
\hline & $33 \mathrm{AB}$ & $53 \mathrm{AB}$ & $61 \mathrm{AB}$ & $67 A B$ \\
\hline $\begin{array}{l}\text { boltwoodite, } \\
{\left[\mathrm{K}_{2}\left(\mathrm{UO}_{2}\right)_{2}\left(\mathrm{SiO}_{3} \mathrm{OH}\right)_{2} \cdot 3 \mathrm{H}_{2} \mathrm{O}\right]}\end{array}$ & 0.47 & 0.31 & 0.32 & 0.53 \\
\hline $\begin{array}{l}\alpha \text {-uranophane, } \\
\mathrm{Ca}\left(\mathrm{UO}_{2}\right)_{2}\left(\mathrm{SiO}_{3} \mathrm{OH}\right)_{2} \cdot 5 \mathrm{H}_{2} \mathrm{O}\end{array}$ & 0.55 & 0.17 & 0.26 & 0.24 \\
\hline $\begin{array}{l}\text { sklodowskite, } \\
\quad \mathrm{Mg}\left(\mathrm{UO}_{2}\right)_{2}\left(\mathrm{SiO}_{3} \mathrm{OH}\right)_{2} \cdot 6 \mathrm{H}_{2} \mathrm{O}\end{array}$ & 0.45 & 0.18 & 0.20 & 0.36 \\
\hline
\end{tabular}

uranophane group mineral. While this distance also agrees with that of a uranyl carbonate mineral, fontanite, this phase has an additional uranium neighbor at $3.7 \AA$ (32), which was not observed; both distances would beobserved if this phase was present.

To verify the presence of a uranophane group mineral, EXAFS spectra of the four samples were analyzed by direct comparison to the spectra of select uranophane group minerals published in Catalano and Brown (17). $\chi_{v}{ }^{2}$ values were calculated for pairs of spectra of the samples and standards (Table 4). This procedure of comparing the EXAFS spectra of unknowns to those of standards is identical to linear-combination least-squares fitting methods used in previous EXAFS studies of metal speciation (35), but with only one component fixed to a fraction of 1.0. While the uranophane group mineral spectra producing the lowest $\chi_{\nu}{ }^{2}$ value varied among the samples, Catalano and Brown (17) demonstrated that the EXAFS spectra of members of the uranophane group are effectively indistinguishable using this method. Thus, the relative $\chi_{v}{ }^{2}$ values for the uranophane group minerals considered cannot be used to evaluate which of these phases is actually present. However, the general range of $\chi_{\nu}{ }^{2}$ values for these phases strongly suggests that one or more uranophane group minerals are the dominant uranium species in thesesamples. As in the above evaluation of the difference among the sample spectra, the variability in the $\chi_{v}{ }^{2}$ values is likely the result of the noise and errors typical of EXAFS data collection and processing. Although thespectra of the related uranophanegroup minerals sodium boltwoodite and $\beta$-uranophane were not available for comparison, the EXAFS spectra of these phases are expected to produce $\chi_{v}{ }^{2}$ values comparable to those of the uranophane group minerals considered in this study due to their similar 


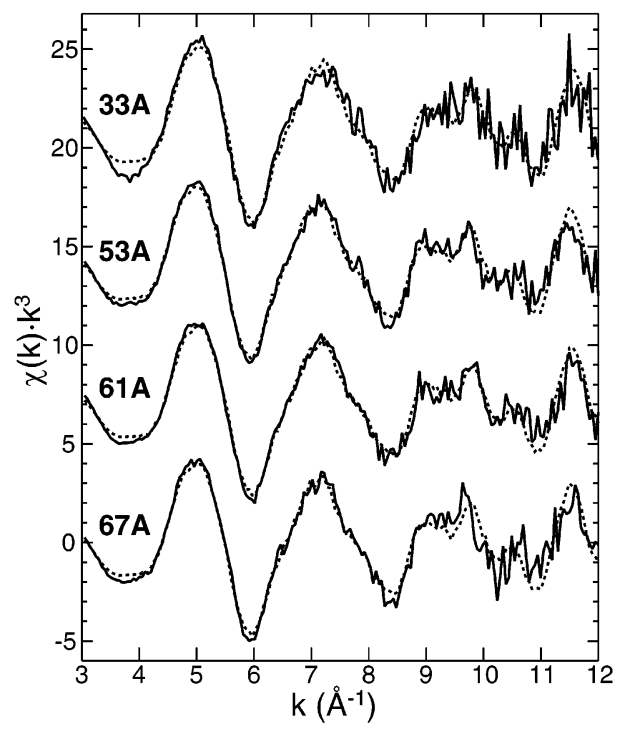

FIGURE 4. Comparison of the four $U L_{\text {III- }}$ edge EXAFS spectra (solid) and the spectrum of $\alpha$-uranophane (dashed).

crystal structures. An example comparison of the EXAFS spectra of the four samples with that of $\alpha$-uranophane is shown in Figure 4. The EXAFS spectra were also refit with an additional silicon shell at $\sim 3.15 \AA$, consistent with the structures of uranophane group minerals; this accurately reproduced the intermediate-range Fourier transform features not fit above (see the Supporting Information).

Uranophane Group Minerals. The uranophane group of minerals is comprised of $\alpha$ - and $\beta$-uranophane [both Ca$\left.\left(\mathrm{UO}_{2}\right)_{2}\left(\mathrm{SiO}_{3} \mathrm{OH}\right)_{2} \cdot 5 \mathrm{H}_{2} \mathrm{O}\right]$, boltwoodite $\left[\mathrm{K}_{2}\left(\mathrm{UO}_{2}\right)_{2}\left(\mathrm{SiO}_{3} \mathrm{OH}\right)_{2} \cdot\right.$ $\left.3 \mathrm{H}_{2} \mathrm{O}\right]$, sodium boltwoodite $\left[\mathrm{Na}_{2}\left(\mathrm{UO}_{2}\right)_{2}\left(\mathrm{SiO}_{3} \mathrm{OH}\right)_{2} \cdot 3 \mathrm{H}_{2} \mathrm{O}\right]$, sklodowskite $\left[\mathrm{Mg}\left(\mathrm{UO}_{2}\right)_{2}\left(\mathrm{SiO}_{3} \mathrm{OH}\right)_{2} \cdot 6 \mathrm{H}_{2} \mathrm{O}\right]$, cuprosklodowskite $\left[\mathrm{Cu}\left(\mathrm{UO}_{2}\right)_{2}\left(\mathrm{SiO}_{3} \mathrm{OH}\right)_{2} \cdot 6 \mathrm{H}_{2} \mathrm{O}\right]$, kasolite $\left[\mathrm{PbUO}_{2} \mathrm{SiO}_{4} \cdot \mathrm{H}_{2} \mathrm{O}\right.$ ], oursinite $\left[(\mathrm{Co}, \mathrm{Mg})\left(\mathrm{UO}_{2}\right)_{2}\left(\mathrm{SiO}_{3} \mathrm{OH}\right)_{2} \cdot 5 \mathrm{H}_{2} \mathrm{O}\right]$, and swamboite [U$\left.\left(\mathrm{UO}_{2}\right)_{6}\left(\mathrm{SiO}_{3} \mathrm{OH}\right)_{6} \cdot 3 \mathrm{H}_{2} \mathrm{O}\right]$ (36). Cuprosklodowskite, kasolite, and oursinite are not expected to form under tank BX-102 on the basis of the sediment and waste stream chemistry. Swamboite is expected to have an EXAFS spectrum significantly different from those of other uranophane group minerals due to the second uranium site in the structure, and thus is not consistent, with regard to the EXAFS data, with the BX-102 samples.

It is highly desirableto determine which of the remaining possible uranophane group minerals is present in the BX102 samples. The solubility of these phases can vary significantly in the sediment porewaters under tank BX-102 (6). Accurate modeling of the future dissolution of these phases, and thesubsequent subsurfacetransport of uranium at this site, requires knowledge of thespecific initial uranium phase(s).

As discussed above, these phasescannot be distinguished using EXAFS spectroscopy due to the similar local structure of uranium. However, these phases have significant differences in their crystal structures, specifically the axislengths (Table5). These differences may beused to distinguish among the uranophane group minerals employing a technique sensitive to variations in long-range structure, such as X-ray diffraction (XRD). Unfortunately, the concentration of uranium, and thus the concentration of uranium-containing crystalline phases, is too low for conventional powder XRD to observethesephases. The use of synchrotron-based $\mu \mathrm{XRD}$ circumvents this problem by selectively diffracting a $\sim 20$ $\mu \mathrm{m}$ diameter beam of X-rays from an area of high uranium concentration. This selectivesampling allows for a significant increase in the strength of the signal from uranium phases. Areas of high uranium concentration can be identified using $\mu$ SXRF.
TABLE 5. Comparison of the Differences in Structure and XRD Patterns of Relevant Uranophane Group Minerals

\begin{tabular}{|c|c|c|c|c|}
\hline \multirow[b]{2}{*}{ mineral } & \multirow[b]{2}{*}{$\begin{array}{c}a \text { axis } \\
\text { length }(\mathbf{A})\end{array}$} & \multirow[b]{2}{*}{$\begin{array}{c}\beta \text { angle } \\
\text { (deg) }\end{array}$} & \multicolumn{2}{|c|}{ strongest reflection } \\
\hline & & & $\begin{array}{c}d \text { spacing } \\
(\AA)\end{array}$ & $\begin{array}{l}\text { Miller index } \\
(h k l)\end{array}$ \\
\hline & $14.154^{f}$ & 104.98 & 6.837 & $(100)$ \\
\hline inditab & 13.931 & 103.21 & 6.78 & (200) \\
\hline & 17.382 & 105.90 & 8.358 & $(200)$ \\
\hline & & 95.70 & 7.91 & (200) \\
\hline & $15.443^{g}$ & $90^{h}$ & 7.721 & (020) \\
\hline
\end{tabular}

a From the structure of Burns (20). ${ }^{b}$ From the cell parameters of Vochten et al. (37) and structure of Burns (20). ' From the structure of Ryan and Rosenzweig (23). ${ }^{d}$ From the structure of Viswanathan and Harneit (19). ${ }^{e}$ From the structure of Ginderow (38). ${ }^{f}$ Axis length multiplied by 2. ${ }^{g} \mathrm{~b}$ axis reported instead of $a$ due to different space group settings. ${ }^{h} \alpha$ angle reported instead of $\beta$ due to different space group settings.

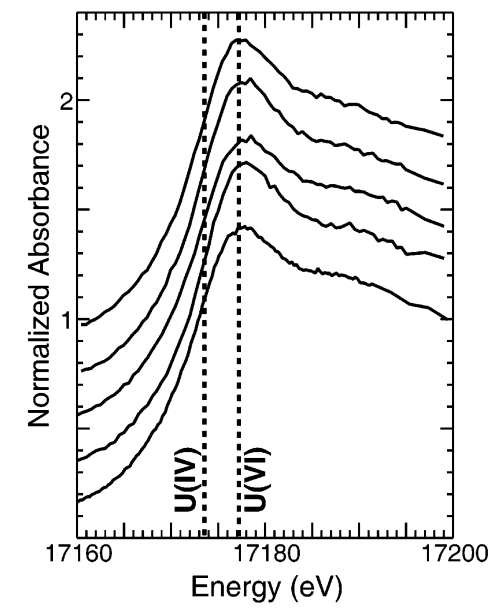

FIGURE 5. Example $\mu$ XANES spectra of areas of high $U$ concentration from sample $61 \mathrm{AB}$.

$\mu$ SXRF and $\mu$ XANES Results. $\mu$ SXRF mapping of the uranium distribution in thin sections of samples $61 \mathrm{AB}$ and 67AB identified numerous areas of high uranium concentration. At these "hotspots", U LIII-edge $\mu$ XANES spectra were collected (Figure 5); the speciation of uranium at all spots analyzed was $\mathrm{U}(\mathrm{VI})$ in the form of uranyl.

$\mu$ XRD Results. $\mu$ XRD patterns were collected on twelve hotspots identified by $\mu$ SXRF, sixper thin section. Theradially integrated and background-subtracted patterns are shown in Figure6. Asall of theraw, 2D patterns contained numerous sharp spots and few powder rings, the relative intensities of the peaks in the processed patterns are not accurate, and quantitativemodeling of the patterns, such as using Rietveld refinement methods to determine the relative percentages of individual phases, is not possible. While too numerous to label individually, most reflections in the patterns with $\mathrm{d}$ spacings less than $6.5 \AA$ ( $2 \theta$ larger than $\sim 6.2^{\circ}$ ) are due to feldspar and quartz grains that comprise the majority of these samples.

Although many of the strongest diffraction lines for the uranophane group minerals occur in the same region as the feldspar and quartz lines, the most intense reflection for each mineral in this group occurs in the relatively "clean" 6.5-8.5 $\AA$ region (Table 5). Examination of this region shows the strongest reflection of sodium boltwoodite was present in four hotspots, three from $61 \mathrm{AB}$ and one from $67 \mathrm{AB}$ (Figure 7). Reflections from other uranophane group minerals were not observed. The lack of reflections from any uranophane group minerals in eight of the patterns is likely due to diffraction from only a small number of uranium-bearing 


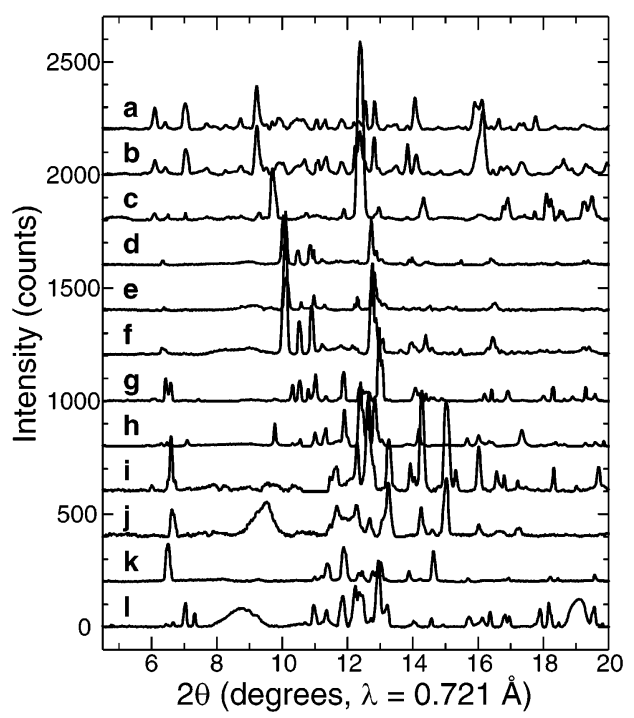

FIGURE 6. Radially integrated and background-subtracted $\mu$ XRD patterns from areas of high $U$ concentration in samples $61 A B(a-f)$ and $67 A B(g-l)$.

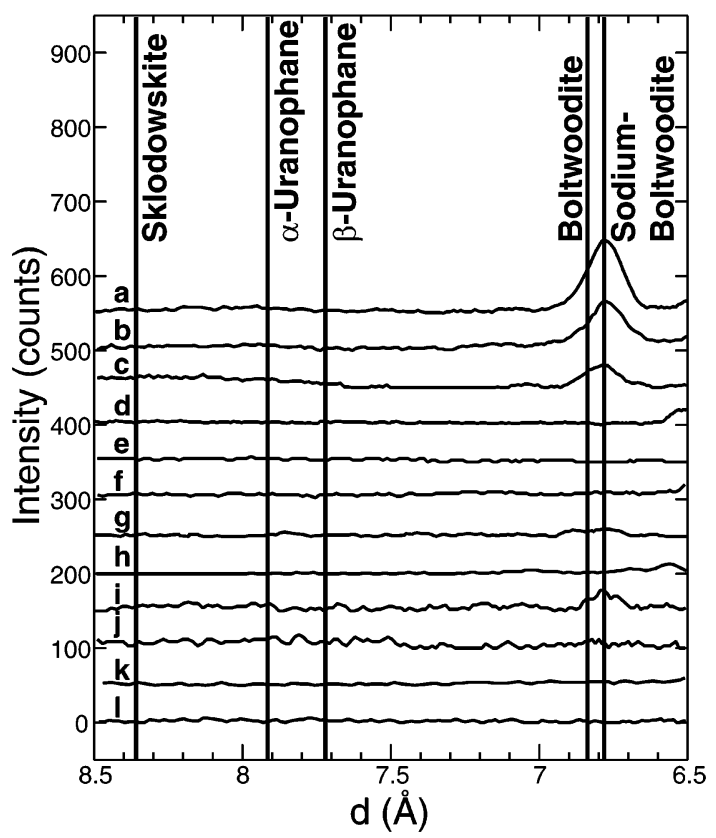

FIGURE 7. $\mu$ XRD patterns from Figure 6 plotted vs $d$ spacing for the region of the most intense lines of uranophane group minerals.

particles, resulting in diffraction peaks that either are too low in intensity to be observed or are not present due to preferred orientation effects. Even if reflections in the $<6.5$ $\AA$ region from a uranophane group mineral were present in these patterns, the significant overlap of these reflections with those from other phases (e.g., quartz and feldspar) in the samples makes identification ambiguous. Additionally, the experimental setup necessary for these experiments requires transmission of the direct and diffracted beams through $\sim 80 \mu \mathrm{m}$ of minerals and epoxy as well as $\sim 1 \mathrm{~mm}$ of glass. These additional phasesinduced a large background and intense point reflections, both of which lead to noise and detector saturation that makes it difficult to observe reflections from phases at low concentration. Although only observed in four patterns, the presence of the primary reflection of sodium boltwoodite and the lack of evidence for other uranophane group minerals suggest that sodium boltwoodite is the primary uranium species present in these samples.
Comparison to Companion Studies. Three companion studies havealso examined thesesamples, and haveobtained consistent and complementary results. Laser-induced fluorescence spectroscopy (LIFS) studies of 61AB, 67AB, and two related samples (53A and $61 \mathrm{~A})$ suggest that the same phase is present in each, and that this phase is likely a uranyl silicate (5). Scanning electron microscope (SEM) observations demonstrate that uranium-bearing phases precipitated in micrometer-scale cracks in plagioclase feldspar grains in samples $61 \mathrm{AB}$ and $67 \mathrm{AB}$ (4). Sediment extractions and aqueous solubility calculations demonstrate that local porewaters associated with samples $53 \mathrm{AB}, 61 \mathrm{AB}$, and $67 \mathrm{AB}$ are close to saturation with respect to sodium boltwoodite (6). The results of the present study and the observations from the three complementary studies are all consistent with the presence of sodium boltwoodite in the contaminated sediments below tank BX-102.

Implications for Long-Term Fate and Remediation. Although thelocal porewater in the contaminated sediments is close to saturation with respect to sodium boltwoodite, with uranium concentrations in the range of $10^{-4}$ to $10^{-3} \mathrm{M}$, no migration of uranium is occurring because of the low moisture content in the vadose zone (5). While a future increase in the sediment water content would likely induce dissolution of the sodium boltwoodite, the occurrence of this phasein microfractures is expected to significantly reduce the release rate of uranium compared to a situation with uranium precipitates exposed directly in larger pores or fractures (5). The contaminated sediments under tank BX102 pose less of an environmental hazard than contaminated sediments under other tanks at thesite. For example, roughly half of the chromium in the contaminant plume under tank $\mathrm{SX}-108$ is in the form of $\mathrm{Cr}(\mathrm{VI})$, which is highly mobile (39).

In the event that remediation of this site is desired by or required of theU.S. Department of Energy (DOE), thesuccess of common remediation strategies will be affected by the speciation and distribution of uranium in these sediments. Example remediation strategies suggested for $\mathrm{U}(\mathrm{VI})$ contamination of soils and groundwater include (1) construction of a permeable reactive barrier (PRB) containing zerovalent iron (40) or hydroxyapatite and bone char (41), (2) microbial reduction to $U(I V)(42-44)$, or (3) leaching with a concentrated bicarbonate solution $(43,45-49)$. The wide spatial distribution of uranium under tank BX-102 suggests that construction of a permeable reactive barrier intersecting the entire $U$ plume is not feasible. Bioremediation through microbial reduction would likely require the introduction of significant quantities of an organic carbon source, and possibly bacteria capable of $\mathrm{U}(\mathrm{VI})$ reduction, as the sediments of the Hanford vadose zone are nutrient-poor and contain relatively low levels of culturable bacteria (50).

Studies of the extraction of uranium from contaminated soils and catch-box media by various leaching solutions demonstrated that sodium bicarbonate solutions could removesignificant quantities of uranium from such materials (46). These samples contained hydrated and dehydrated forms of schoepite, uranium metal, and unidentified U(IV) phases, although the relative proportions of these species were not determined, and it is unclear if the sodium bicarbonate extractions removed all $\mathrm{U}(\mathrm{VI})$ phases. Leaching of uranium from a contaminated soil with a concentrated sodium bicarbonate solution was partially successful at another DOE facility, the Fernald site in Ohio (47). At this site, uranium was present as distinct, separate grains, primarily as autunite-like and schoepite-like phases, with minor uranium(IV) oxides and phosphates (51). The differences in uranium speciation between these studies and that observed under tank BX-102 make it is difficult to predict the effectiveness of sodium bicarbonate extraction procedures at this site. In addition, the microscale spatial distribution 
of uranium in the BX-102 sediments creates a significant physical limitation to uranium extraction. The presence of sodium boltwooditepredominantly in fractures in plagioclase feldspar grains restricts the interaction of these particles with the bulk porewater. These chemically distinct microenvironments only interact with the interparticle porewater at fracture openings, suggesting that diffusion of bicarbonate into thesecracks and uranyl tricarbonate solution complexes out of them may be the rate-limiting steps in the extraction of uranium from these sediments.

\section{Acknowledgments}

This research was supported by DOE-EMSP Grant FG07ER0263495 (Stanford) and Battelle Contract 409089-A9EP3623. We thank Jeff Serne, Paul Gassman, Steve Smith, and Zheming Wang (PNNL) for preparing and shipping the XAFS samples and thin sections to SSRL and the APS. We also thankJ ohn Bargar and Joe Rodgers (SSRL) for their technical support on beamline 11-2 prior to data collection at SSRL and Ian Evans, Ray Russ, and Carol Morris of the Stanford Linear Accelerator Center Health Physics staff for their help in the safe handling of the radioactive samples at SSRL. Thanks arealso extended to JulieCross and DaleBrewe (PNCCAT) for assistance with data collection at the APS and to Peter Eng, Steve Sutton, and Vitali Prakapenka (GSECARS) for providing the detector for the microdiffraction experiments. The final paper benefited from the input of three anonymous reviewers. SSRL is supported by the U.S. Department of Energy, Office of Basic Energy Sciences and Office of Biological and Environmental Research, and the National Institutes of Health, National Center for Research Resources, Biomedical Technology Program. Use of the APS was supported by the U.S. Department of Energy, Office of Science, Office of Basic Energy Sciences, under Contract W-31-109-Eng-38. PNC-CAT is supported by funding from the U.S. Department of Energy-Basic Energy Sciences, the National Science Foundation, the University of Washington, the Natural Sciences and Engineering Research Council of Canada, and Simon Fraser University.

\section{Supporting Information Available}

One figure and one table. This material is available free of charge via the Internet at http:// pubs.acs.org.

\section{Literature Cited}

(1) Riley, R. G.; Zachara, J. M. Chemical Contaminants on DOE Lands and Selection of Contaminant Mixtures for Subsurface Science Research; Report DE92 014826; U.S. Department of Energy, Office of Energy Research: Washington, DC, 1992.

(2) Jones, T. E.; Simpson, B. C.; Wood, M. I.; Corbin, R. A. Preliminary Inventory Estimates for Single-Shell Tank Leaks in B, BX, and BYTank Farms; Report RPP-7389; CH2M HILL Hanford Group, Inc.: Richland, WA, 2001.

(3) Serne, R. J.; Last, G. V.; Gee, G. W.; Schaef, H. T.; Lanigan, D. C.; Lindenmeier, C. W.; Lindberg, M. J.; Clayton, R. E.; LeGore, V. L.; Orr, R. D.; Kutnyakov, I. V.; Baum, S. R.; Geiszler, K. N.; Brown, C. F.; Valenta, M. M.; Vickerman, T. S. Characterization of VadoseZoneSediment: Borehole299-E33-45 Near BX-102 in the B-BX-BY Waste Management Area; PNNL-14083; Pacific Northwest National Laboratory: Richland, WA, 2002.

(4) McKinley, J. P.; Zachara, J. M.; Liu, C.; Heald, S. M. Geochim. Cosmochim. Acta, submitted for publication.

(5) Wang, Z.; Zachara, J. M.; Gassman, P. L.; Liu, C.; Qafoku, O.; Catalano, J. G. Geochim. Cosmochim. Acta, submitted for publication.

(6) Liu, C.; Zachara, J. M.; Qafoku, O.; McKinley, J. P.; Heald, S. M.; Wang, Z. Geochim. Cosmochim. Acta, in press.

(7) Bargar, J. R.; Brown, G. E., Jr.; Evans, I.; Rabedeau, T.; Rowen, M.; Rogers, J. Proceedings of the Euroconference and NEA Workshop on Speciation, Techniques and Facilities for Radioactive Materials at Synchrotron Light Sources; NEA/OECD: Paris, 2002; pp 57-68.
(8) George, G. N.; Pickering, I. F. EXAFSPAK; Stanford Synchrotron Radiation Laboratory: Menlo Park, CA, 2000.

(9) Webb, S. M. SixPACK; Stanford Synchrotron Radiation Laboratory: Menlo Park, CA, 2003.

(10) Newville, M. J. Synchrotron Radiat. 2001, 8, 322-324.

(11) Demartin, F.; Gramaccioli, C. M.; Pilati, T. Acta Crystallogr. 1992, C48, 1-4.

(12) Ankudinov, A. L.; Rehr, J. J. Phys. Rev. B: Condens. Matter 1997, 15, R1712-R1715.

(13) Hudson, E. A.; Allen, P. G.; Terminello, L. J.; Denecke, M. A.; Reich, T. Phys. Rev. B: Condens. Matter 1996, 54, 156-165.

(14) Hammersley, A. P. FIT2D: An Introduction and Overview; Internal Report ESRF97HA02T; European Synchrotron Radiation Facility: Grenoble, France, 1997.

(15) Farges, F.; Ponader, C. W.; Calas, G.; Brown, G. E., Jr. Geochim. Cosmochim. Acta 1992, 56, 4205-4220.

(16) Hudson, E. A.; Rehr, J. J.; Bucher, J. J. Phys. Rev. B: Condens. Matter 1995, 52, 13815-13826.

(17) Catalano, J. G.; Brown, G. E., Jr. Am. Mineral., in press.

(18) Burns, P. C. In Uranium: Mineralogy, Geochemistry and the Environment; Burns, P. C., Finch, R., Eds.; Reviews in Mineralogy 38; Mineralogical Society of America: Washington, DC, 1999; pp 23-90.

(19) Viswanathan, K.; Harneit, O. Am. Mineral. 1986, 71, 1489-1493.

(20) Burns, P. C. Can. Mineral. 1998, 36, 1069-1075.

(21) Rosenzweig, A.; Ryan, R. R. Am. Mineral. 1975, 60, 5-6.

(22) Rosenzweig, A.; Ryan, R. R. Cryst. Struct. Commun. 1977, 6, $617-621$.

(23) Ryan, R. R.; Rosenzweig, A. Cryst. Struct. Commun. 1977, 6, 611-615.

(24) Demartin, F.; Diella, V.; Donzelli, S.; Gramaccioli, C. M.; Pilati, T. Acta Crystallogr. 1991, B47, 439-446.

(25) Jackson, J. M.; Burns, P. C. Can. Mineral. 2001, 39, 187-195.

(26) Burns, P. C. Can. Mineral. 2001, 39, 1153-1160.

(27) Finch, R. J.; Cooper, M. A.; Hawthorne, F. C.; Ewing, R. C. Can. Mineral. 1996, 34, 1071-1088.

(28) Pagoaga, M. K.; Appleman, D. E.; Stewart, J. M. Am. Mineral. 1987, 72, 1230-1238.

(29) Burns, P. C. Can. Mineral. 1998, 36, 1061-1067.

(30) Locock, A. J.; Burns, P. C. J. Solid State Chem. 2002, 163, 275280.

(31) Finch, R. J.; Cooper, M. A.; Hawthorne, F. C.; Ewing, R. C. Can. Mineral. 1999, 37, 929-938.

(32) Hughes, K. A.; Burns, P. C. Am. Mineral. 2003, 88, 962-966.

(33) Burns, P. C.; Deely, K. M.; Hayden, L. A. Can. Mineral. 2003, 41, 687-706.

(34) Brandenburg, N. P.; Loopstra, B. O. Acta Crystallogr. 1978, B34, $3734-3736$.

(35) Manceau, A.; Marcus, M. A.; Tamura, N. In Applications of Synchrotron Radiation in Low-Temperature Geochemistry and Environmental Sciences; Fenter, P. A., Rivers, M. L., Sturchio, N. C., Sutton, S. R., Eds.; Reviews in Mineralogy and Geochemistry 49; Mineralogical Society of America and the Geochemical Society: Washington, DC, 1999; pp 341-428.

(36) Finch, R.; Murakami, T. In Uranium: Mineralogy, Geochemistry and the Environment; Burns, P. C., Finch, R., Eds.; Reviews in Mineralogy 38; M ineralogical Society of America: Washington, DC, 1999; pp 91-179.

(37) Vochten, R.; Blaton, N.; Peeters, O.; Van Springel, K.; Van Haverbeke, L. Can. Mineral. 1997, 35, 735-741.

(38) Ginderow, D. Acta Crystallogr. 1988, C44, 421-424.

(39) Zachara, J. M.; Ainsworth, C. C.; Brown, G. E., Jr.; Catalano, J. G.; McKinley, J. P.; Qafoku, O.; Smith, S. C.; Szecsody, J. E.; Traina, S. J.; Warner, J. A. Geochim. Cosmochim. Acta 2004, 68, 13-30.

(40) Gu, B.; Liang, L.; Dickey, M. J.; Yin, X.; Dai, S. Environ. Sci. Technol. 1998, 32, 3366-3373.

(41) Fuller, C. C.; Bargar, J. R.; Davis, J. A.; Piana, M. J. Environ. Sci. Technol. 2002, 36, 158-165.

(42) Lovley, D. R.; Phillips, E. J. P.; Gorby, Y. A.; Landa, E. R. Nature 1991, 350, 413-416.

(43) Phillips, E. J. P.; Landa, E. R.; Lovley, D. R. J. Ind. Microbiol. 1995, 14, 203-207.

(44) Finneran, K. T.; Anderson, R. T.; Nevin, K. P.; Lovley, D. R. Soil Sediment Contam. 2002, 11, 339-357.

(45) Buck, E. C.; Brown, N. R.; Dietz, N. L. Environ. Sci. Technol. 1996, 30, 81-88.

(46) Duff, M. C.; Mason, C. F. V.; Hunter, D. B. Can. J. Soil Sci. 1998, $78,675-683$.

VOL. 38, NO. 10, 2004 / ENVIRONMENTAL SCIENCE \& TECHNOLOGY • 2827 
(47) Mason, C. F. V.; Turney, W. R. J. R.; Thomson, B. M.; Lu, N.; Longmire, P. A.; Chisholm-Brause, C. J. Environ. Sci. Technol. 1997, 31, 2707-2711.

(48) Osiensky, J. L.; Williams, R. E. Ground Water Monit. Rem. 1990, $10,107-112$.

(49) Sheppard, S. C.; Evenden, W. G. Arch. Environ. Contam. Toxicol. 1992, 23, 117-124.

(50) Fredrickson, J. K.; Brockman, F. J.; Bjornstad, B. N.; Long, P. E.; Li, S. W.; McKinley, J. P.; Wright, J. V.; Conca, J. L.; Kieft, T. L.; Balkwill, D. L. Geomicrobiol. J. 1993, 11, 95-107.
(51) Morris, D. E.; Allen, P. G.; Berg, J. M.; Chisholm-Brause, C. J.; Conradson, S. D.; Donohoe, R. J.; Hess, N. J.; Musgrave, J. A.; Tait, C. D. Environ. Sci. Technol. 1996, 30, 2322-2331.

Received for review January 7, 2004. Revised manuscript received March 9, 2004. Accepted March 16, 2004.

ES049963E 